(REVIEW ARTICLE)

\title{
Adjuvant chemotherapy for malignant phyllodes tumor of the breast
}

\author{
Bruno Henrique Rala de Paula ${ }^{1,2, *}$, Renata de Souza Guerra ${ }^{2}$, Carlos Augusto Moreira de Sousa ${ }^{3}$ and \\ Susanne Crocamo ${ }^{3}$
}

\author{
${ }^{1}$ Department of Oncology - University of Cambridge, Cambridge, United Kingdom. \\ 2 University of Vassouras, Vassouras, Brazil. \\ ${ }^{3}$ Instituto Nacional de Cancer (INCA), Rio de Janeiro, Brazil.
}

Publication history: Received on 25 February 2020; revised on 05 March 2020; accepted on 06 March 2020

Article DOI: https://doi.org/10.30574/wjarr.2020.5.3.0052

\begin{abstract}
Malignant phyllodes tumor of the breast (MPTB) is rare and usually presents as a large rapidly progressive mass which might metastasize distantly. The survival benefit of breast surgery is unquestionable; on the other hand, adjuvant radiotherapy and chemotherapy are controversial. In this study, chemotherapy endpoints are reviewed and underlying factors related to the outcomes are discussed. We performed a systematic review based on studies reporting diseasefree survival (DFS) and/or overall survival (OS) rates with chemotherapy as variable in MPTB patients. The search generated 246 studies and 3 were included. They present together 199 patients, 77 (39\%) with aggressive histology and $29(15 \%)$ received chemotherapy. One study reported better DFS and OS outcomes in treatment group whilst two reported the opposite, but neither results were statistically significant. Unbalanced arms, small sample size, absence of prognostic factors stratification and inclusion of indolent subtypes are factors that might have contributed to these results. Therefore, the negative benefit of adjuvant chemotherapy in survival of MPTB is based on few studies with considerable limitations. High risk MPTB should be properly studied in randomized prospective trials, specially taking into account prognostic and predictive molecular markers of response.
\end{abstract}

Keywords: Adjuvant chemotherapy; Breast cancer; Phyllodes

\section{Introduction}

Phyllodes tumors represent less than $1 \%$ of all breast neoplasms and the malignant subtype 10 to $30 \%$. It usually presents as a large mass restricted to the breast [1]. Lymph node metastasis rate is $15 \%$ and impairs prognosis. The overall rate of all distant metastasis is 4\% although higher for borderline 25\% and MPT 31\% [2].

MPTB are historically reported as refractory to current therapeutic options due to sarcomatous/stromal components, associated with poor response to chemotherapy and primary expression of estrogen receptor-beta un-targetable by hormonal-therapy [3].

Interestingly, chemotherapy promotes benefit in palliative setting such as MAID (Doxorubicin, Dacarbazine, Ifosfamide, and Mesna). In retrospective analysis from breast sarcomas treated with MAID regimen, partial response was 50\% with respectively DFS and OS medians of 2.5 and 5 months [4].

Treatment based on appropriate surgery with clear margins when locally-advanced. Whilst adjuvant radiotherapy improves survival, chemotherapy seems not [5]. However, is suggested in high-risk tumors [6]. Although studies of systemic therapy are negative the reasons for such is poorly explored by literature.

\footnotetext{
* Corresponding author: Bruno Henrique Rala de Paula
} 
We conducted a literature review to primarily assess the factors contributing to the absence of adjuvant chemotherapy benefit in MPTB.

\section{Methodology}

Using PubMed an electronic search was performed without restrictions (Figure1). Population was phyllodes tumors of the breast, intervention - adjuvant chemotherapy, comparison - no treatment or placebo, outcomes - disease free and overall survival, study design allowed - cohort studies and clinical trials.
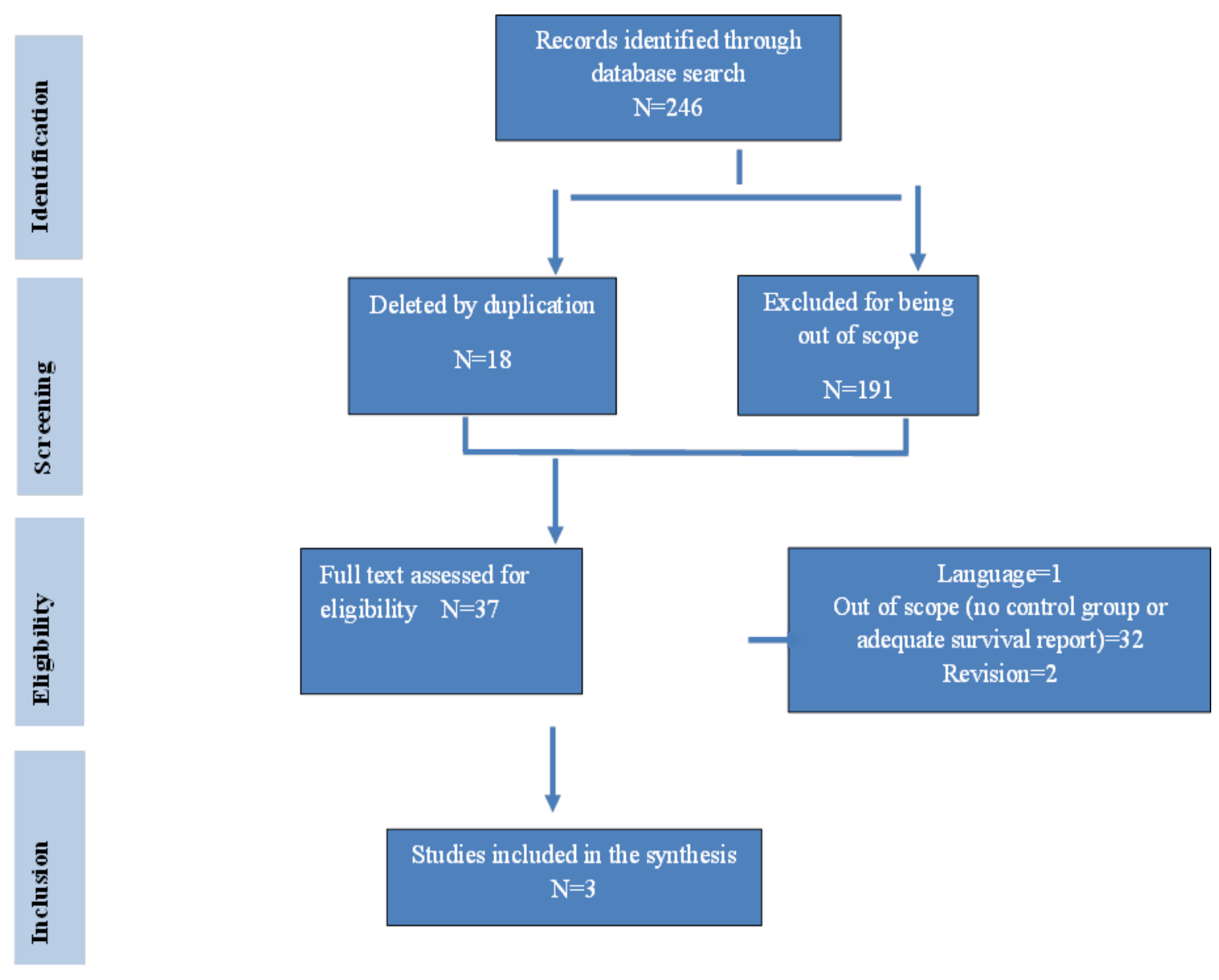

Figure 1 Flow diagram

\section{Results}

Two hundred and forty-six records were generated after the databases screening, 243 excluded. Therefore, three studies were included in the review according the study flowchart (Figure 1).

The studies presented together 199 phyllodes tumors, 128 (55\%) were MPTB and 29 (15\%) received chemotherapy with adjuvant intention.

In first study published in 2007, Morales et al prospectively evaluated 28 Mexican patients from 1993 to 2003 which 17 were exposed to chemotherapy versus no treatment for 11 patients. Second study published in 2015 Wang et al retrospectively evaluated 70 MPT e 35 primary breast sarcomas (PM) in a Chinese cancer centre from 1995 to 2010. Third study published in 2000, Chaney et al assessed 101 phyllodes tumors, 30 of them malignant. Patients were treated between 1944 and 1998, at M. D. Anderson Cancer Centre. All patients received primary surgery in both studies. Relevant information of each study was summarized on Table 1. 
Table 1 Study summarized information

\begin{tabular}{|c|c|c|c|c|c|c|}
\hline & \multicolumn{2}{|c|}{ Morales. F et al. 2007 [7] } & \multicolumn{2}{|c|}{ Wang. F et al. 2015 [8] } & \multicolumn{2}{|c|}{ Chaney, A et al. 2000 [2] } \\
\hline \multicolumn{7}{|c|}{ Study and sample characteristics } \\
\hline Design & \multicolumn{2}{|c|}{ Prospective not randomized } & \multicolumn{2}{|c|}{ Retrospective analysis } & \multicolumn{2}{|c|}{ Retrospective analysis } \\
\hline Phyllodes tumors sample & \multicolumn{2}{|l|}{$28(100 \%)$} & \multicolumn{2}{|l|}{$70(100 \%)$} & \multicolumn{2}{|l|}{$101(100 \%)$} \\
\hline Accrual period & \multicolumn{2}{|l|}{$1993-2003$} & \multicolumn{2}{|l|}{$1995-2010$} & \multicolumn{2}{|l|}{ 1944-1998 } \\
\hline Aggressive component & \multicolumn{2}{|l|}{$28(100 \%)$} & \multicolumn{2}{|l|}{$19(27 \%)$} & \multicolumn{2}{|l|}{$30(30 \%)$} \\
\hline Tumor size $<5 \mathrm{~cm}$ & \multicolumn{2}{|l|}{$2(7 \%)$} & \multicolumn{2}{|l|}{$38(53 \%)$} & \multicolumn{2}{|l|}{$41(48 \%)$} \\
\hline $5 \mathrm{~cm}<$ Tumor size $<10 \mathrm{~cm}$ & \multicolumn{2}{|l|}{$6(21 \%)$} & \multicolumn{2}{|l|}{$25(34 \%)$} & \multirow{2}{*}{\multicolumn{2}{|c|}{$45(52 \%)$}} \\
\hline Tumor size $>10 \mathrm{~cm}$ & \multicolumn{2}{|l|}{$20(71 \%)$} & \multicolumn{2}{|l|}{$7(10 \%)$} & & \\
\hline Stromal Overgrowth & \multicolumn{2}{|l|}{ Not reported } & \multicolumn{2}{|l|}{ Not reported } & \multicolumn{2}{|l|}{$29(30 \%)$} \\
\hline Mitotic Index & \multicolumn{2}{|l|}{ Not reported } & \multicolumn{2}{|l|}{ Not reported } & \multicolumn{2}{|l|}{ Not reported } \\
\hline \multicolumn{7}{|c|}{ Local and systemic treatment } \\
\hline Mastectomy & \multicolumn{2}{|l|}{$24(86 \%)$} & \multicolumn{2}{|l|}{$27(39 \%)$} & \multicolumn{2}{|l|}{$54(54 \%)$} \\
\hline Conservative surgery & $4(14 \%)$ & & $43(61 \%)$ & & $47(46 \%)$ & \\
\hline Axillary dissection & $13(46 \%)$ & & $24(34 \%)$ & & $26(26 \%)$ & \\
\hline Lymph node positive & Not reported & & $0(0)$ & & $0(0)$ & \\
\hline Positive margin & $11(39 \%)$ & & Not reported & & $1(1 \%)$ & \\
\hline Radiotherapy & $7(25 \%)$ & & $0(0)$ & & $6(6 \%)$ & \\
\hline Chemotherapy Regimen & $\begin{array}{l}\text { Doxorubicin } \\
\text { Dacarbazine } 9 \\
\text { intravenous } \\
\text { cycles) }\end{array}$ & $\begin{array}{l}5 \mathrm{mg} / \mathrm{m}^{2} \text { and } \\
0 \mathrm{mg} / \mathrm{m}^{2}-48 \mathrm{~h} \\
\text { nfusion (four }\end{array}$ & Not reported & & $\begin{array}{l}\text { Doxorubicin } \\
\text { Ifosfamide-bas }\end{array}$ & $\begin{array}{r}\text { and } \\
\text { d regimens }\end{array}$ \\
\hline Local recurrence & $\begin{array}{l}\text { Value not res } \\
\text { described as } n \\
\text { the adjuvant } \\
\text { group. }\end{array}$ & $\begin{array}{l}\text { ealed, although } \\
\text { ore frequent in } \\
\text { chemotherapy }\end{array}$ & $9(12.9 \%)$ & & $4(4 \%)$ & \\
\hline $\begin{array}{l}\text { Post-surgery treatment } \\
\text { arm }\end{array}$ & Intervention & Control & Intervention & Control & Intervention & Control \\
\hline Sample Size (percentage) & $17(61 \%)$ & $11(39 \%)$ & $8(8 \%)$ & $97(92 \%)$ & $4(4 \%)$ & $96(96 \%)$ \\
\hline Disease-free survival & $58 \%$ & $58 \%$ & $63 \%$ & $69 \%$ & $100 \%$ & $88 \%$ \\
\hline Overall survival & $86 \%$ & $90 \%$ & $63 \%$ & $79 \%$ & $100 \%$ & $92 \%$ \\
\hline
\end{tabular}


Table 2 Clinical characteristics and survival outcomes of malignant phyllodes tumor reported in literature

\begin{tabular}{|c|c|c|c|c|c|c|c|c|c|c|}
\hline \multirow{2}{*}{$\begin{array}{l}\text { Author, } \\
\text { year and } \\
\text { median } \\
\text { follow up } \\
\text { time }\end{array}$} & \multirow{2}{*}{$\begin{array}{l}\text { Study } \\
\text { subgroups } \\
\text { of interest }\end{array}$} & \multirow{2}{*}{$\begin{array}{l}\text { Number of } \\
\text { subjects } \\
(\%)\end{array}$} & \multirow{2}{*}{$\begin{array}{l}\text { Median } \\
\text { tumor } \\
\text { size } \\
\text { (cm) }\end{array}$} & \multicolumn{2}{|c|}{$\begin{array}{l}\text { Local } \\
\text { Recurrence }\end{array}$} & DFS & \multicolumn{2}{|c|}{$\begin{array}{l}\text { Overall } \\
\text { Survival }\end{array}$} & \multirow{2}{*}{$\begin{array}{l}\text { Distant } \\
\text { metastasis } \\
\text { rate }\end{array}$} & \multirow{2}{*}{ Relevant Acknowledgements } \\
\hline & & & & $\begin{array}{l}5 \\
\text { years }\end{array}$ & $\begin{array}{l}10 \\
\text { years }\end{array}$ & 5 years & & $\begin{array}{l}10 \\
\text { years }\end{array}$ & & \\
\hline \multirow{5}{*}{$\begin{array}{l}\text { Chaney, } \\
2000[2]\end{array}$} & Total & $101(100 \%)$ & 6 & $98 \%$ & $92 \%$ & $94 \%$ & $88 \%$ & $79 \%$ & $7.92 \%$ & \multirow{5}{*}{$\begin{array}{l}\text { - Almost all malignant tumors } \\
\text { expressed stromal overgrowth in } \\
\text { pathological evaluation } \\
\text { - Stromal overgrowth, malignant } \\
\text { histology, and mastectomy, } \\
\text { correlates with distant metastasis. } \\
\text { - Stromal overgrowth was found to be } \\
\text { a statistically significant predictor of } \\
\text { distant outcome and survival }\end{array}$} \\
\hline & $\begin{array}{l}\text { MPT chemotherapy } \\
\text { group }\end{array}$ & $4(4 \%)$ & & & & & $10 \% *$ & & & \\
\hline & $\begin{array}{l}\text { MPT non-chemotherapy } \\
\text { group }\end{array}$ & $97(96 \%)$ & & & & & $88 \%$ & & & \\
\hline & Stromal overgrowth & $29(29 \%)$ & & & & & $81 \%$ & $42 \%$ & & \\
\hline & Malignant tumors & $30(30 \%)$ & & & & & $82 \%$ & $42 \%$ & $23 \%$ & \\
\hline \multirow{2}{*}{$\begin{array}{l}\text { Guillot, } \\
2011[10]\end{array}$} & Total & $165(100 \%)$ & 3 & & $85 \%$ & & & & $1.21 \%$ & \multirow{5}{*}{$\begin{array}{l}\text { - Histological grade and tumor size } \\
\text { were significant risk factors for loca } \\
\text { recurrence, with a higher risk wher } \\
\text { tumors are borderline or with } \\
\text { larger size }\end{array}$} \\
\hline & $\begin{array}{l}\text { MPT chemotherapy } \\
\text { group }\end{array}$ & $5(3 \%)$ & & & & & & & & \\
\hline \multirow{3}{*}{$\begin{array}{l}\text { Median } \\
\text { Follow-up } \\
\text { 13(months) }\end{array}$} & $\begin{array}{l}\text { MPT non-chemotherapy } \\
\text { group }\end{array}$ & $160(97 \%)$ & & & & & & & & \\
\hline & Stromal overgrowth & & & & & & & & & \\
\hline & Malignant tumors & $14(8 \%)$ & & & & & & & & \\
\hline \multirow{5}{*}{$\begin{array}{l}\text { Morales, } \\
2007[7]\end{array}$} & Total & $28(100 \%)$ & 13 & & & $68 \% *$ & $82 \% *$ & & $25 \%$ & \multirow{5}{*}{$\begin{array}{l}\text { - Dose, agents and number of cycles } \\
\text { might be important to achieve the } \\
\text { curative intent. } \\
\text { - Unbalance between interventional } \\
\text { and control group of unknown } \\
\text { prognostic factors might have } \\
\text { contributed to the worse } \\
\text { performance of the interventional } \\
\text { arm }\end{array}$} \\
\hline & $\begin{array}{l}\text { MPT chemotherapy } \\
\text { group }\end{array}$ & $17(61 \%)$ & & & & $58 \%$ & $76 \%$ & & & \\
\hline & $\begin{array}{l}\text { MPT non-chemotherapy } \\
\text { group }\end{array}$ & $11(39 \%)$ & & & & $86 \%$ & $90 \%$ & & & \\
\hline & Stromal overgrowth & & & & & & & & & \\
\hline & Malignant tumors & $28(100 \%)$ & & & & & & & & \\
\hline
\end{tabular}


Rala et al. / World Journal of Advanced Research and Reviews, 2020, 05(03), 048-054

\begin{tabular}{|c|c|c|c|c|c|c|c|c|c|}
\hline \multirow{2}{*}{$\begin{array}{l}\text { Wang. } \quad \text { F., } \\
2014[8]\end{array}$} & Total & $105(100 \%)$ & 5 & & & & & & \multirow{6}{*}{$\begin{array}{l}\text { - Tumor size was a prognostic } \\
\text { indicator of DFS and OS }\end{array}$} \\
\hline & MPT group & $70(67 \%)$ & & $75 \%$ & $68 \%$ & $78 \%$ & & & \\
\hline \multirow[t]{4}{*}{$N R$ (months) } & $\begin{array}{l}\text { MPT chemotherapy } \\
\text { group }\end{array}$ & $8(8 \%)$ & & & $63 \%$ & $63 \%$ & & & \\
\hline & $\begin{array}{l}\text { MPT non-chemotherapy } \\
\text { group }\end{array}$ & $62(59 \%)$ & & & $69 \%$ & $79 \%$ & & & \\
\hline & Stromal overgrowth & & & & & & & & \\
\hline & Malignant tumors & $19(18 \%)$ & & & & & & & \\
\hline \multirow{2}{*}{$\begin{array}{l}\text { Asoglu, } \\
2004[11]\end{array}$} & Total & $50(100 \%)$ & 3.5 & & & $75 \%$ & $57 \%$ & $26 \%$ & \multirow{5}{*}{$\begin{array}{l}\text { - The stromal overgrowth was a } \\
\text { statistically significant independent } \\
\text { predictor of distant metastasis }\end{array}$} \\
\hline & $\begin{array}{l}\text { MPT chemotherapy } \\
\text { group }\end{array}$ & $2(4 \%)$ & & & & & & & \\
\hline \multirow[t]{3}{*}{$\begin{array}{l}91 \\
\text { (months) }\end{array}$} & $\begin{array}{l}\text { MPT non-chemotherapy } \\
\text { group }\end{array}$ & $48(96 \%)$ & & & & & & & \\
\hline & Stromal overgrowth & $12(24 \%)$ & & & & & & & \\
\hline & Malignant tumors & $50(100 \%)$ & & & & & & $26 \%$ & \\
\hline \multirow{5}{*}{$\begin{array}{l}\text { Belkacemi, } \\
2007[1]\end{array}$} & Total & $443(100 \%)$ & \multirow[t]{5}{*}{ NR } & & $83 \%$ & $97 \%$ & $96 \%$ & $3.4 \%$ & \multirow{5}{*}{$\begin{array}{l}\text { Favorable prognostic factors } \\
\text { included premenopausal status, } \\
\text { small histologic tumor size, low } \\
\text { number of mitosis, lower cellular } \\
\text { atypia, absence of stromal } \\
\text { overgrowth, no tumor necrosis, } \\
\text { absence of residual tumor after initial } \\
\text { treatment, and clear margins. }\end{array}$} \\
\hline & $\begin{array}{l}\text { MPT chemotherapy } \\
\text { group }\end{array}$ & $13(3 \%)$ & & & & & & & \\
\hline & $\begin{array}{l}\text { MPT non-chemotherapy } \\
\text { group }\end{array}$ & $430(97 \%)$ & & & & & & & \\
\hline & Stromal overgrowth & $15(3 \%)$ & & & & & & & \\
\hline & Malignant tumors & 79 (18\%) & & & & & & & \\
\hline
\end{tabular}

Legenda: MPT - Malignant phyllodes tumors rate, LRR - Local recurrence rate, DFS - Disease-free survival rate (years); OS - Overall survival rate (years); Blank spaces are data not reported; * - Data calculate 


\section{Discussion}

This is the first review dedicated exclusively to assessing the role of adjuvant chemotherapy in malignant phyllodes tumors of the breast. It raises the hypothesis for the negative results of chemotherapy being possibly attributed to study biases mainly related to accrual period, to the phyllodes tumors heterogeneous subtypes and the lack of balance between the arms.

Accrual was considerably long amongst studies, ten years in the single prospective although not randomized study to 54 in the American cohort $[2,7]$. Technology in cancer care changes every decade, especially about optimum margin in breast surgery for these tumors [9]. Therefore, a considerable difference in machinery and pathology is expected in a half century.

Interestingly, patients on chemotherapy group on both Chinese and Mexican study experienced a poor performance compared to the control group, although without statistical significance $[7,8]$. This might be influenced by the absence intervention balance amongst arms which a small percentage received chemotherapy in the larger studies (8\% [8] and $4 \%$ [2]) and the opposite was seen in the clinical trial (61\% [7]).

Mitotic index and stromal overgrowth as known significant prognostic factors also were not controlled in the randomization of the clinical trial or reported in most studies [2,7,8]. Additionally, 73\% of the patients from the Chinese and $70 \%$ from the American study had an indolent histology, such as low grade or borderline and known to be refractory to chemotherapy $[2,8]$. In the only available guideline, the above characteristics are core to recommend adjuvant chemotherapy since are stated to define the high-risk group together with tumor size and presence of necrosis [6].

Phyllodes tumors of the breast are a subtype from a heterogeneous group of fibro-epithelial tumors with different proportion of components stromal and epithelial [3]. As shown by Table 2, it includes generally a benign, borderline and malignant variants associated with distinct histological characteristic, prognostics and treatment sensitivity [6]. It thus seems rational to suggest from the molecular and biological point of view a multicentric prospective randomized clinical trial to properly evaluate an adjuvant chemotherapy regimen similar to soft-tissue sarcomas versus best supportive care in breast phyllodes tumor. Inclusion criteria should be restricted to malignant histology and the primary objective disease free-survival.

Although this study provides contributions in the contemporary approach to this rare tumor subtype, it must be seen in light of his limitations. Publications on the topic are extremely scarce, most evidences are series of cases or case reports and the larges studies had considerable level of bias. Comparison between studies is challenging but all account with a humbled sample size of patients in the intervention group. There is also a considerable heterogeneity in study population, poor uniformity in chemotherapy regimens, lack of control of prognostic factors in randomization and different follow-up times.

\section{Conclusion}

To date, adjuvant chemotherapy does not improve survival outcomes in malignant phyllodes tumor of the breast. This could be eventually justified by stratification due to prognostic factors and limited number of patients on tumor with a higher likelihood of benefit based on clinical, pathological and molecular criteria. This might potentially.

\section{Compliance with ethical standards}

\section{Acknowledgments}

We thank the University of Vassouras (USS) and Instituto Nacional de Cancer (INCA) to collaborate together for the production of this paper.

\section{Disclosure of conflict of interest}

The authors above declare absence of interest conflict. 


\section{References}

[1] Belkacémi Y, Bousquet G, Marsiglia H, Ray-Coquard I, Magné N, Malard Y, et al. (2008). Phyllodes tumor of the breast. Int J Radiat Oncol Biol Phys, 70 (2), 492-500.

[2] Chaney AW, Pollack A, McNeese MD, Zagars GK, Pisters PW, Pollock RE, et al. (2000). Primary treatment of cystosarcoma phyllodes of the breast. Cancer, 89 (7), 1502-1511.

[3] Tse GMK, Lee CS, Kung FYL, Scolyer RA, Law BKB, Lau T, et al. (2002). Hormonal receptors expression in epithelial cells of mammary phyllodes tumors correlates with pathologic grade of the tumor: a multicentre study of 143 cases. Am J Clin Pathol, 118, 522-526.

[4] Mouna B, Rhizlane B, Boutayeb S and Errihani H. (2012). The efficacy of chemotherapy against metastatic malignant phyllodes tumors of the breast. J Clinic Case Reports, 2.

[5] Chao X, Chen K, Zeng J, Bi Z, Guo M, Chen Y, et al. (2019). Adjuvant radiotherapy and chemotherapy for patients whit breast phyllodes tumors: a systematic review and meta-analysis. BMC Cancer, 19, 372.

[6] ESMO. (2018). Soft tissue and visceral sarcomas: ESMO-EURACAN. Clinical practice guidelines for diagnosis, treatment and follow-up. Annals of Oncology, 29.

[7] Morales-Vásquez F, Gonzalez-Angulo AM, Broglio K, Lopez-Basave HN, Gallardo D, Hortobagyi GN, et al. (2007). Adjuvant chemotherapy whit doxorubicin and dacarbazine has no effect in recurrence-free survival of malignant phyllodes tumors of the breast. The Breast Journal, 13 (6), 551-556.

[8] Wang F, Jia Y and Tong Z. (2015). Comparison of the clinical and prognostic features of primary breast sarcomas and malignant phyllodes tumor. Jpn J Clin Oncol, 45 (2), 146-152.

[9] Ogunbiyi S, Perry A, Jakate K, Simpson J and George R. (2019). Phyllodes tumour of the breast and margins: how much is enough? Can J Surg, 62 (1), 19-21.

[10] Guillot E, Couturaud B, Reyal F, Curnier A, Ravinet J, Laé M, et al. (2011). Management of phyllodes breast tumors. The Breast Journal, 12 (2), 129-137.

[11] Asoglu O, Ugurlu MM, Blanchard K, Grant CS, Reynolds C and Cha SS. (2004). Risk factors for recurrence and death after primary surgical treatment of malignant phyllodes tumors. Ann Surg Oncol, 11 (11), 1011-1017.

\section{How to cite this article}

De Paula BHR, Guerra RS, Moreira De Sousa CA and Crocamo S. (2020). Adjuvant chemotherapy for malignant phyllodes tumor of the breast. World Journal of Advanced Research and Reviews, 5(3), 48-54. 